\title{
STATUS KEBERSIHAN GIGI DAN MULUT PADA ANAK AUTIS DI KOTA MANADO
}

\author{
${ }^{1}$ Monica M. Sengkey \\ ${ }^{2}$ Damajanty H. C. Pangemanan \\ ${ }^{2}$ Christy N. Mintjelungan
}

\author{
${ }^{1}$ Kandidat Skripsi Program Studi Kedokteran Gigi Fakultas Kedokteran \\ ${ }^{2}$ Bagian Fisiologi Fakultas Kedokteran \\ ${ }^{3}$ Program Studi Kedokteran Gigi Fakultas Kedokteran \\ Universitas Sam Ratulangi Manado \\ Email: monicasengkey@yahoo.co.id
}

\begin{abstract}
The most common tooth and mouth health problems in autisic children are dental caries, periodontal diseases, oral cavity disorders, tooth eruption disorder, and trauma. This study aimed to obtain the tooth and mouth hygienic status of autistic children in Manado. This was a descriptive observational study with a cross sectional design. Population was all autistic students registered in AGCA Manado dan Sekolah Khusus Anak Autis Permata Hati. There were 94 students aged 6-21 years. Samples were 51 students obtained by using total sampling and fulfilled the inclusion criteria. The results showed that the tooth and mouth hygienic status of autistic children was mostly categorized as moderate and poor, each of $39.21 \%$. Based on gender, poor category of OHI-S status was the most frequent in males $(42.5 \%)$ meanwhile in females good and moderate categories, each of $36.36 \%$. Based on age, the moderate category of OHI-S status was in age group 6-10 years $(42.31 \%)$, meanwhile poor category was found in age group 11-15 years $(47.62 \%)$ and 16-21 years $(75 \%)$. The average OHI-S index of autistic children in Manado was 2,77, categorized as moderate. Conclusion: In general, OHI-S status of autistic children in Manado was in moderate category, with an average OHI-S index of 2,77 .
\end{abstract}

Keywords: OHI-S, autistic children

\begin{abstract}
Abstrak: Masalah-masalah kesehatan gigi dan mulut yang paling sering dijumpai pada anak autis yaitu karies gigi, penyakit periodontal, kerusakan lingkungan rongga mulut, kelainan erupsi gigi, dan trauma. Penelitian ini bertujuan untuk mengetahui status kebersihan gigi dan mulut anak autis di kota Manado. Jenis penelitian yaitu deskriptif observasional dengan pendekatan potong lintang.. Populasi penelitian yaitu seluruh anak autis yang terdaftar sebagai siswa sekolah AGCA Manado dan Sekolah Khusus Anak Autis Permata Hati berjumlah 94 anak berusia 6-21 tahun. Sampel sejumlah 51 anak dilakukan dengan teknik total sampling dan memenuhi kriteria inklusi. Hasil penelitian menunjukkan bahwa status kebersihan gigi dan mulut pada anak autis di kota Manado tertinggi yaitu berada pada kategori sedang dan buruk masing-masing $39,21 \%$. Berdasarkan jenis kelamin, status OHI-S terbanyak pada laki-laki yaitu kategori buruk $42,5 \%$, sedangkan pada perempuan yaitu kategori baik dan sedang masing-masing 36,36\%. Berdasarkan kelompok umur, status OHI-S terbanyak pada kelompok umur 6-10 tahun yaitu sedang (42,31\%), pada kelompok umur 11-15 (47,62\%) dan 16-21 tahun yaitu buruk (75\%). Rata-rata indeks OHI-S pada anak autis di kota Manado yaitu 2,77 dengan kategori sedang. Simpulan: Umumnya status OHI-S anak autis di Kota Manado berada pada kategori sedang dengan indeks OHI-S rata-rata yaitu 2,77.
\end{abstract}

Kata kunci: OHI-S, anak autis 
Ditinjau dari sudut pandang kebutuhan akan pelayanan kesehatan, khususnya kesehatan gigi dan mulut, maka kelompok anak berkebutuhan khusus lebih membutuhkan dibandingkan anak-anak pada umumnya. Anak-anak berkebutuhan khusus, karena berbagai keterbatasan yang ada pada mereka, seperti kurang mampu untuk membersihkan sendiri rongga mulutnya, sehingga meningkatkan faktor risiko kerusakan gigi-gigi dan jaringan lunak sekitarnya. Proses tumbuh kembang anak memerlukan pemenuhan kebutuhan makanan yang baik dan adekuat. Kesehatan gigi dan mulut penting dalam upaya mendapatkan asupan makanan yang cukup mengingat bahwa dalam rongga mulut terdapat alat pengunyahan. Anak berkebutuhan khusus, terutama yang mengalami gangguan saraf motorik mempunyai risiko malnutrisi dan kesehatan rongga mulut yang buruk. ${ }^{1}$

Anak-anak berkebutuhan khusus bermacam-macam, salah satunya yaitu autis. Autis merupakan gangguan perkembangan yang memengaruhi beberapa aspek bagaimana anak melihat dunia dan belajar dari pengalamannya. Anak-anak dengan gangguan autis biasanya kurang dapat merasakan kontak sosial. Mereka cenderung menyendiri dan menghindari kontak dengan orang lain. Autis merupakan salah satu bentuk gejala akibat adanya kelainan syaraf tertentu yang menyebabkan fungsi otak tidak bekerja secara normal sehingga memengaruhi tumbuh kembang, kemampuan komunikasi dan kemampuan interaksi sosial seseorang. ${ }^{2}$

Masalah-masalah kesehatan gigi dan mulut yang paling sering dijumpai pada anak autis yaitu karies gigi, penyakit periodontal, kerusakan lingkungan rongga mulut, kelainan erupsi gigi, dan trauma. Kesehatan gigi dan mulut anak autis sangat bergantung pada perilaku orang tua dimana orang tua berperan sebagai orang terdekat dari anak yang senantiasa mendidik, melatih dan memberikan kasih sayang kepada anak. Selain daripada orang tua, guru di sekolah juga memegang peranan yang sangat penting, hal ini dikarenakan seorang guru merupakan model bagi subjek didiknya. Orang tua dan guru harus memiliki bekal pelatihan dalam mendidik dan mengajarkan anak untuk bersikap peduli pada kesehatan gigi dan mulut serta kesehatan tubuh secara umumnya. ${ }^{3,4}$

Kesehatan gigi dan mulut penting untuk diperhatikan dan merupakan bagian integral dari kesehatan secara keseluruhan yang memerlukan penanganan segera sebelum terlambat dan dapat mempengaruhi kondisi kesehatan seseorang. Kesehatan gigi dan mulut perlu ditingkatkan di seluruh lingkungan keluarga dan masyarakat. Kebersihan gigi adalah suatu keadaan dimana gigi geligi yang berada dalam rongga mulut yang berada diatas permukaan gigi seperti debris, karang gigi dan sisa makanan. ${ }^{5,6}$

Status kebersihan gigi dan mulut adalah keadaan kebersihan mulut dari seseorang yang dinilai dari adanya sisa makanan dan kalkulus pada permukaan gigi yang diukur dengan indeks Oral Hygiene Index Simplified dari Green and Vermillion 1964. Status kebersihan gigi dan mulut (OHI-S) merupakan jumlah indeks debris (DI) dan indeks kalkulus (CI). Umumnya indeks digunakan untuk menilai pengumpulan plak gigi menggunakan skala numerik untuk mengukur bagian permukaan gigi yang tertutup oleh plak. ${ }^{7}$

Untuk pemeriksaan DI-S (debris indeks) digunakan sonde yang diletakkan pada 1/3 incisal dan digerakkan 1/3 gingival sesuai dengan skor yang telah ditentukan. Untuk kalkulus indeks (CI-S) diperoleh dengan meletakkan sonde dengan baik dalam distal gingival crevice dan digerakkan pada daerah subgingival dari jurusan kontak distal ke daerah kontak mesial (1/2 dari lingkaran gigi dianggap sebagai satu unit skoring). ${ }^{7}$

Autis merupakan suatu gangguan perkembangan yang menunjukan adanya sindrom perilaku yaitu interaksi sosial dan perkembangan sosial abnormal, tidak 
mampu mengadakan komunikasi yang normal, minat serta aktifitasnya sangat terbatas, kaku, sering mengulang apa yang dia ketahui dan tanpa imajinasi. ${ }^{8}$ Autis dianggap sebagai gangguan perilaku atau gangguan psikiatri yang disebabkan oleh kerusakan genetik yang sulit untuk dapat disembuhkan. ${ }^{9}$

Bentuk penanganan yang dilakukan pada anak-anak yang menderita autis berkisar pada terapi pendidikan atau modifikasi tingkah laku yang kadangkadang ditambah dengan obat-obatan penenang. ${ }^{9}$ Anak autis adalah anak yang mengalami gangguan perkembangan yang kompleks yang mulai tampak sebelum anak berusia tiga tahun, bahkan anak yang termasuk autis infantile gejalanya sudah muncul sejak lahir. ${ }^{10}$

Autis Center Sulawesi Utara, Association Growing Children Autism (AGCA) Center Manado dan Sekolah Khusus Anak Autis Permata Hati merupakan pusat pelayanan, yayasan dan sekolah khusus anak-anak penyandang autis yang ada di kota Manado dan secara resmi bekerja sama dengan pemerintah kota dalam rangka pendidikan, pelayanan kesehatan serta terapi khusus bagi anak autis.

\section{BAHAN DAN METODE}

Penelitian ini dilakukan di dua sekolah khusus anak autis yang ada di kota Manado yaitu Association Growing Children Autism (AGCA) Center Manado dan Sekolah Khusus Anak Autis Permata Hati Manado pada bulan Maret -Juni tahun 2015. Populasi penelitian ini ialah seluruh anak autis yang terdaftar sebagai siswa sekolah AGCA Manado dan Sekolah Khusus Anak Autis Permata Hati dengan total populasi berjumlah 94 anak berusia 6-21 tahun. Sampel yang digunakan sebesar 51 anak dan menggunakan metode total sampel berdasarkan kriteria inklusi.
Pengambilan data dengan mengisi data siswa yang menjadi sampel pada formulir yang terdiri dari nama, tanggal lahir, jenis kelamin dalam formulir wawancara. Data pemeriksaan status kebersihan gigi dan mulut diperoleh saat masing-masing siswa diperiksa di AGCA Center Manado dan Sekolah Khusus Permata Hati Manado.

Semua data yang diperoleh, diolah dan dianalis menggunakan program komputer Microsoft Excel 2010 kemudian disajikan dalam bentuk tabel distribusi frekuensi berdasarkan hasil persentase.

\section{HASIL PENELITIAN}

Karakteristik subjek penelitian dibedakan atas jenis kelamin dan kelompok usia.

Tabel 1. Distribusi frekuensi karakteristik responden berdasarkan jenis kelamin

\begin{tabular}{ccc}
\hline Jenis Kelamin & $\mathrm{n}$ & $\%$ \\
\hline Laki-laki & 40 & 78,43 \\
Perempuan & 11 & 21,57 \\
\hline Total & 51 & 100 \\
\hline
\end{tabular}

Tabel 2. Distribusi frekuensi karakteristik responden berdasarkan usia

\begin{tabular}{ccc}
\hline $\begin{array}{c}\text { Umur } \\
\text { (tahun) }\end{array}$ & $\mathrm{n}$ & $\%$ \\
\hline $6-10$ & 26 & 50,98 \\
$11-15$ & 21 & 41,18 \\
$16-21$ & 4 & 7,84 \\
\hline Total & 51 & 100 \\
\hline
\end{tabular}

Tabel 3. Status kebersihan gigi dan mulut responden

\begin{tabular}{ccc}
\hline $\begin{array}{c}\text { Status } \\
\text { kebersihan mulut }\end{array}$ & $\mathrm{n}$ & $\%$ \\
\hline Baik & 11 & 21,58 \\
Sedang & 20 & 39,21 \\
Buruk & 20 & 39,21 \\
\hline Total & 51 & 100 \\
\hline
\end{tabular}


Sengkey, Pangemanan, Mintjelungan: Status kebersihan gigi dan mulut pada anak autis ...

Tabel 4. Status OHI-S berdasarkan karakteristik jenis kelamin

\begin{tabular}{|c|c|c|c|c|c|c|c|c|}
\hline \multirow{3}{*}{$\begin{array}{l}\text { Jenis } \\
\text { kelamin }\end{array}$} & \multicolumn{6}{|c|}{ Status OHI-S } & \multirow{2}{*}{\multicolumn{2}{|c|}{ Total }} \\
\hline & \multicolumn{2}{|c|}{ Baik } & \multicolumn{2}{|c|}{ Sedang } & \multicolumn{2}{|c|}{ Buruk } & & \\
\hline & $\mathrm{n}$ & $\%$ & $\mathrm{n}$ & $\%$ & $\mathrm{n}$ & $\%$ & $\mathrm{n}$ & $\%$ \\
\hline Laki-laki & 7 & 17,5 & 16 & 40 & 17 & 42,5 & 40 & 100 \\
\hline Perempuan & 4 & 36,36 & 4 & 36,36 & 3 & 27,28 & 11 & 100 \\
\hline Total & 11 & 21,58 & 20 & 39,21 & 20 & 39,21 & 51 & 100 \\
\hline
\end{tabular}

Tabel 5. Status OHI-S berdasarkan karakteristik kelompok umur

\begin{tabular}{ccccccccc}
\hline \multirow{2}{*}{$\begin{array}{c}\text { Umur } \\
\text { (tahun) }\end{array}$} & \multicolumn{9}{c}{ Status OHI-S } & \multirow{2}{*}{ Total } \\
\cline { 2 - 7 } & \multicolumn{2}{c}{ Baik } & \multicolumn{2}{c}{ Sedang } & \multicolumn{2}{c}{ Buruk } & & \\
\cline { 2 - 8 } & $\mathrm{n}$ & $\%$ & $\mathrm{n}$ & $\%$ & $\mathrm{n}$ & $\%$ & $\mathrm{n}$ & $\%$ \\
\hline $6-10$ & 8 & 30,77 & 11 & 42,31 & 7 & 26,92 & 26 & 100 \\
$11-15$ & 3 & 14,29 & 8 & 38,09 & 10 & 47,62 & 21 & 100 \\
$16-21$ & 0 & 0 & 1 & 25 & 3 & 75 & 4 & 100 \\
Total & 11 & 21,58 & 20 & 39,21 & 20 & 39,21 & 51 & 100 \\
\hline
\end{tabular}

Tabel 6. Distribusi rata -rata indeks OHI-S

\begin{tabular}{cccc}
\hline DI & CI & Jumlah & $\begin{array}{c}\text { Rata-rata } \\
\text { OHI-S }\end{array}$ \\
\hline 72,54 & 68,65 & 141,19 & 2,77 \\
\hline
\end{tabular}

\section{BAHASAN}

Tabel 1 menunjukkan bahwa responden dengan jenis kelamin laki-laki $(78,43 \%)$ lebih banyak dari responden jenis kelamin perempuan $(21,57 \%)$.

Distribusi kelompok umur menunjukkan bahwa karakteristik umur responden pada kelompok umur terbanyak pada 6-10 tahun $(50,98 \%)$, diikuti kelompok umur 1115 tahun $(41,18 \%)$ dan kelompok umur 16-21 tahun (7,84\%) (Tabel 2).

Status OHI-S pada anak autis dibedakan menjadi tiga kategori yakni kategori baik, sedang dan buruk. Kategori status OHI-S baik didapati pada 11 responden (21,58\%), kategori sedang didapati pada 20 responden $(39,21 \%)$ dan kategori buruk didapati pada 20 responden $(39,21 \%)$ (Tabel 3).
Status OHI-S berdasarkan karakteristik jenis kelamin menunjukkan bahwa status OHI-S kategori buruk lebih banyak dialami oleh laki-laki yakni oleh 17 responden $(42,50 \%)$ diikuti oleh kategori sedang yakni oleh 16 responden $(40 \%)$ dan kategori baik 7 responden $(17,50 \%)$. Pada jenis kelamin perempuan status OHI-S kategori baik dan sedang memiliki persentase yang sama yakni masing-masing pada 4 responden $(36,36 \%)$ diikuti kategori buruk yakni 3 responden $(27,28 \%$ ) (Tabel 4).

Status OHI-S berdasarkan karakteristik umur menunjukkan bahwa kelompok umur 6-10 tahun status OHI-S kategori sedang merupakan kategori status OHI-S yang paling banyak didapati yakni pada 11 siswa $(42,31 \%)$, kategori baik yakni pada 8 siswa $(30,77 \%)$ dan kategori buruk yakni pada 7 siswa $(26,92 \%)$. Kelompok umur 11-15 tahun status OHI-S kategori buruk merupakan kategori status OHI-S yang paling banyak didapati yakni pada 10 siswa (47,62\%), kategori sedang yakni pada 8 
siswa $(38,09 \%)$ dan kategori baik yakni pada 3 siswa (14,29\%). Kelompok umur 16-21 tahun tahun status OHI-S kategori buruk merupakan kategori status OHI-S yang paling banyak didapati yakni pada 3 siswa (75\%), kategori sedang yakni pada 1 siswa (25\%) (Tabel 5).

Rata-rata indeks OHI-S pada anak autis di kota Manado yang berjumlah 51 siswa memiliki jumlah OHI-S 141,19 dan rata-rata OHI-S yaitu 2,77. Hasil ini menunjukkan bahwa anak autis di kota Manado memiliki indeks OHI-S kategori sedang (Tabel 6).

Data hasil penelitian memberikan gambaran bahwa secara umum status OHI$S$ anak autis di Kota Manado berada pada kategori sedang dengan indeks OHI-S ratarata yaitu 2,77 . Indeks $\mathrm{OHI}-\mathrm{S}$ rata-rata tersebut dapat disebabkan oleh minimnya pengetahuan mengenai pemeliharaan kebersihan gigi dan mulut dalam rangka mencegah terjadinya kerusakan gigi dan penyakit lainnya. Hal ini sesuai dengan informasi yang diperoleh di sekolahsekolah tersebut yang menyatakan bahwa belum pernah ada kunjungan dari tenaga kesehatan khususnya dokter gigi di sekolah-sekolah tersebut dalam rangka pemeriksaan maupun penyuluhan mengenai kesehatan gigi dan mulut.

Data hasil penelitian menunjukkan bahwa usia 6-10 tahun merupakan kelompok umur yang memiliki persentase status OHI-S sedang terbanyak yakni didapati pada 11 anak (42,31\%). Hal ini disebabkan karena kelompok usia ini masih tergolong usia sangat muda untuk membersihkan rongga mulut secara individual dimana orang tua seringkali mengalami kesulitan untuk mengajarkan cara menyikat gigi pada anak-anak kelompok usia ini. Penelitian ini ditunjang oleh penelitian yang dilakukan oleh Shapira et al. yang menyatakan bahwa anak autis dibawah 11 tahun maupun anak autis yang tidak bersekolah rata-rata memiliki tingkat kebersihan rongga mulut yang buruk. Sama halnya seperti anak normal pada umumnya, semakin dewasa maka anak autis juga semakin memahami dan mengerti bahkan melakukan secara baik mengenai pemeliharaan kebersihan gigi. ${ }^{1}$

Data hasil penelitian mengenai status OHI-S pada anak autis berdasarkan jenis kelamin memberikan gambaran bahwa status OHI-S buruk lebih banyak didapati pada laki-laki dibandingkan perempuan yaitu 17 anak (42,50\%). Pada penelitian ini didapati lebih banyak laki-laki dengan status OHI-S buruk dibandingkan perempuan dikarenakan dalam penelitian ini anak autis dengan dengan jenis kelamin laki-laki jumlahnya lebih banyak dibandingkan perempuan. Penderita autis pun sering terjadi pada anak laki-laki. Jumlah anak autis pada anak laki-laki empat sampai lima kali lipat dibandingkan dengan anak perempuan. Pada anak lakilaki terdapat 1 anak autis dari 70 anak, sedangkan pada perempuan terdapat 1 anak autis dari 315 anak. $^{12}$

\section{SIMPULAN}

Dari hasil penelitian dapat disimpulkan bahwa umumnya status OHI-S anak autis di Kota Manado berada pada kategori sedang dengan indeks OHI-S rata-rata yaitu 2,77. Usia 6-10 tahun merupakan kelompok umur yang memiliki persentase status OHI$\mathrm{S}$ sedang terbanyak.

\section{SARAN}

Disarankan agar pemerintah dapat lebih memperhatikan kesehatan gigi dan mulut khususnya pada anak autis melalui program-program peningkatan kesehatan gigi dan mulut seperti kunjungan dokter gigi di sekolah-sekolah khusus autis serta penyuluhan kesehatan gigi dan mulut. Orang tua disarankan untuk lebih berperan aktif dalam menjaga kesehatan gigi dan mulut anak autis.

\section{DAFTAR PUSTAKA}

1. Titien I. Peran dokter gigi dalam tumbuh kembang anak berkebutuhan khusus. Majalah Kedokteran Gigi. 2012;XIX 
(2):176-80.

2. Widuri RW, Joeda AS Penanganan kemampuan interaksi sosial anak autis. Jurnal Pendidikan Khusus. 2013;3(3):12.

3. Fahmi RR. Hubungan kebersihan gigi dan mulut terhadap karies gigi pada anak penyandang autismedi Sekolah Autis Harapan Aisyiyah Mojokerto [Skripsi]. Jember: Ilmu Kedokteran Gigi Masyarakat Universitas Jember, 2012.

4. Abdurarahman M. Pendidikan bagi anak berkesulitan belajar. Jakarta: Rineka Cipta, 2003; p. 1-5.

5. Nurhidayat $O$, Tunggul EP, Wahyono $B$. Perbandingan media power point dengan flip chart dalam meningkatkan pengetahuan kesehatan gigi dan mulut. Unnes Journal of Public Health. 2012;1(1):32.

6. Jamil JA. Hubungan antara mengonsumsi jajanan dengan pengalaman karies pada gigi susu anak usia 4-6 tahun di TK Medan [Skripsi]. Medan: Universitas Sumatra Utara, 2011.

7. Carranza FA. Glickman's Clinical Periondontology (9th ed.). Philadelphia: WB Saunders, 2003; p. 728-45.
8. Monika, Waruwu FE. Anak berkebutuhan khusus bagaimana mengenal dan menanganinya. Jurnal Provitae. 2006;2(2):7-10

9. Aritonang E, Pardede A, Eka E. Pengetahuan, sikap dan tindakan ibu dalam pola makan anak penderita autis di Yayasan Tali Kasih. Jurnal Kedokteran Indonesia. 2009;1(1):1027.

10. Supartini E. Program Son-rise untung pengembangan bahasa anak autis. Jurnal Pendidikan Khusus. 2009;5(2):44-54.

11. Shapira J, Mann J, Tamari I, Mester R, Knobler H, Yoeli Y, Newbrunt E. Oral health status and dental needs of an autistic population of children and young adults. Spec Care Dentist. US National Library of Medicine; Mar-Apr 1989;9(2):38-41.

12. Centers for Disease Control and Prevention (CDC). Prevalance of autism spectrum disorders - autism and developmental disabilities monitoring network. MMWR Surveill Summ 2009. United States. 2006. 58(55-10). 